\title{
Soil-plant Relationships in the Central Kruger National Park
}

\author{
S.W. FRASER, T.H. VAN ROOYEN and E. VERSTER
}

Fraser, S.W., T.H. van Rooyen and E. Verster. 1987. Soil-plant relationships in the central Kruger National Park. - Koedoe 30: 19-34. Pretoria. ISSN $0075-6458$.

\begin{abstract}
There is a significant relationship between the tree communities and the soils in the Mooiplaas-Mahlangeni region of the central Kruger National Park. Shrub savanna dominated by Colophospermum mopane (mopane) as a multiplestemmed shrub occurs on all the fine-textured soils derived from basic rocks i.e. basalts, diabase and olivine gabbro. Mixed savanna woodlands dominated by either mopane or Combretum apiculatum (red bushwillow) occur on the coarse-textured soils derived from granitic gneiss. The red bushwillow is dominant on the more shallow soils. Mopane occurs in very dense stands as either stunted trees or as single-stemmed shrubs on most duplex soils. Relatively low-lying areas with saline soils are treeless. Terminalia sericea (silver clusterleaf) is characteristic of deeper coarse-textured and somewhat poorly drained soils.
\end{abstract}

Key words: Kruger National Park, soil types, vegetation, Colophospermum mopane, Combretum apiculatum, Terminalia sericea, Mooiplaas-Mahlangeni region.

S.W. Fraser, T.H. van Rooyen and E. Verster, Department of Geography, University of South Africa, P.O. Box 392, Pretoria, 0001 Republic of South Africa.

\section{Introduction}

The geographic distribution of natural plant communities is dependent upon several interrelated factors: (i) environment, i.e. climatic, biotic and edaphic factors; (ii) the physiological reaction of plants within their limits of tolerance for environmental conditions; and (iii) genetic factors that determine tolerance limits, generate variability and create potential for adaption and population expansion (Mason 1946). Kruckeberg (1969) stated that the physical and chemical properties of soils (edaphic factor) can elicit sharp discontinuities in plants, and that soils of highly contrasting lithological origin exert marked selective effects on floras.

Soils hold and supply the water and provide the nutrients that are essential for plant growth. In a study of the vegetation of the Etosha National Park, Le Roux (1980) concluded that the clay content and moisture index of the soil were the most important components of the ecosystem affecting the vegetation. Henning (1980) found that slight differences in water content and flow capacity were responsible 
for changes in the vegetation community within an extensive homogeneous soil body.

It is clear that soils are a distinct and important factor in plant ecology, and this close relationship between soils and vegetation is a useful aid in the mapping of these resources. The purpose of this paper is to describe the relationship between soil type and natural vegetation, in particular some tree types of the Mooiplaas and Mahlangeni regions of the central Kruger National Park, an area where a pedological survey was carried out in order to obtain more soil information (Fraser 1983).

\section{Methods}

The soils were identified and classified according to the South African binomial system (MacVicar, De Villiers, Loxton, Verster, Lambrecht, Merryweather, Le Roux, Van Rooyen \& Harmse 1977). A soil association map (scale 1:50 000) was compiled employing normal field techniques.

For the assessment of the vegetation communities, squares measuring $20 \mathrm{~m} \times 20 \mathrm{~m}$ were demarcated within areas of selected soil series and the encompassed trees and shrubs were identified, counted and grouped into height classes of $1 \mathrm{~m}$ intervals. Twelve soil series were selected and samples of the main soil horizons from within the squares were collected and analysed for particle size and soil reaction. Four to six sample counts were completed for each soil series, and the tree density per hectare calculated.

\section{Discussion}

\section{Environmental features}

The study area (Fig. 1) forms part of the Transvaal Lowveld with its characteristic semi-arid, warm climate. The average annual rainfall is about $475 \mathrm{~mm}$ with a summer rainfall dominance, and the mean monthly temperature ranges from $26^{\circ} \mathrm{C}$ in January to $17^{\circ} \mathrm{C}$ in July (Fraser 1983).

The solid geology comprises two major units namely the basement granitoids and basalt of the Karoo Sequence. The former, consisting of granitic gneiss, extend over most of the Mahlangeni region, whereas the Mooiplaas region is underlain by basalt of the Lebombo Group (Fig. 2). Also occurring in the Mahlangeni region are diabase/dolerite dykes with a predominantly south-west to north-east alignment, and sills of olivine gabbro. The basalt has been subdivided by Cleverly \& Bristow (1979) into three distinct formations: Mashikiri Nephelinite, Letaba Basalt and Sabie River Basalt. The oldest of these, the Mashikiri Nephelinite, outcrops as a thin sequence of alkaline (nephelinite) lava flows. This basalt is more resistant to weathering, and forms a line of low hills running from north to south. The Letaba Basalt is olivine-rich, whereas the Sabie River Basalt comprises dark, finegrained generally aphyric flows. There appears to be significant areal differences in composition especially in the latter formation, and this may lead to further subdivisions (Cleverly \& Bristow 1979). Of minor occurrence is a narrow outcrop 

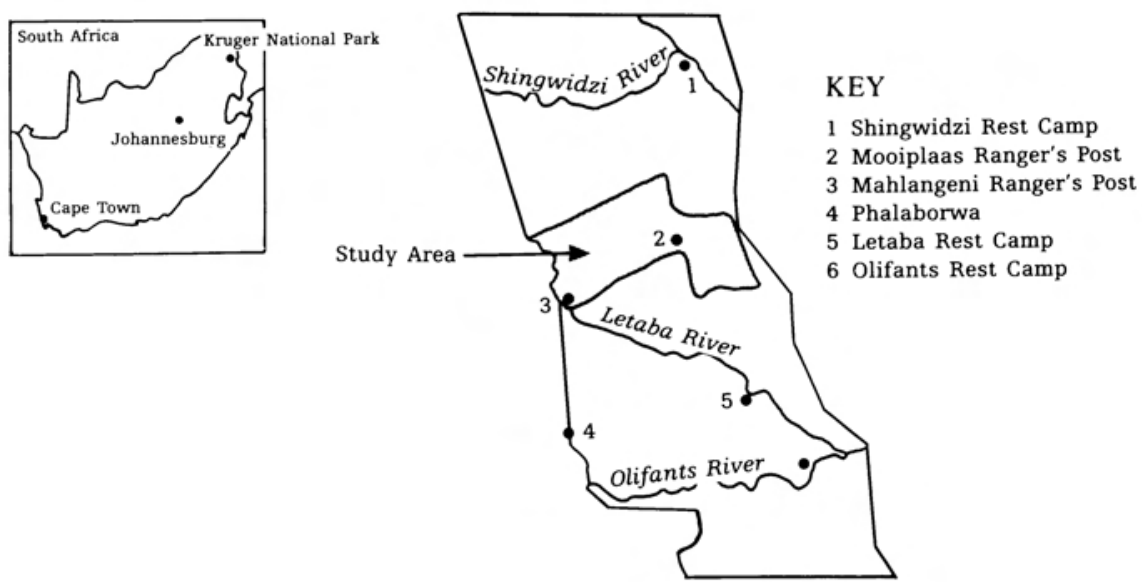

Fig. 1. Map showing the location of the study area in the central Kruger National Park.

of Karoo sedimentary rock (Clarence Formation) which forms a thin partition between the gneiss and basalt (Fig. 2). Flanking the area in the east is the Lebombo monocline consisting of rhyolite. This was excluded from the study.

Morphologically the land surface can be described as plains with low relief (Fig. 2). On the granitic gneiss of the Mahlangeni region the plain is slightly undulating with convex to straight curvature. Local relief is $35 \mathrm{~m}-80 \mathrm{~m}$ and isolated inselbergs are scattered over the area. The plain of the Mooiplaas region, underlain by basalt, is flat and featureless with generally straight curvature, except for a line of low hills, underlain by Mashikiri nephelinite, the highest of which rises

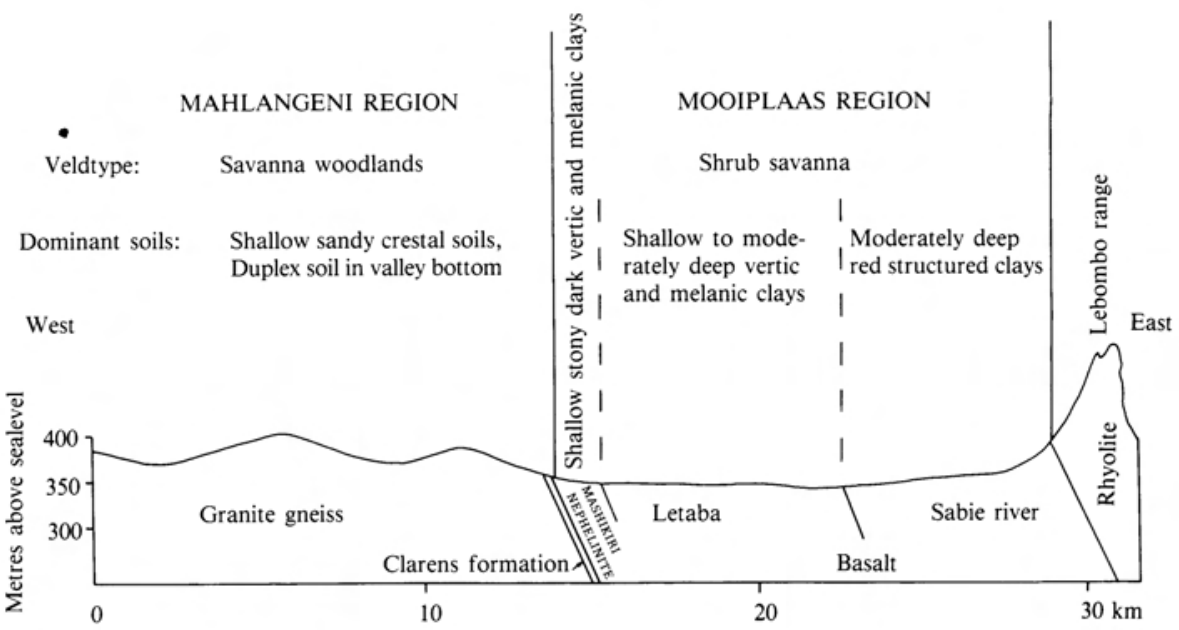

Fig. 2. Schematic representation showing the relationship between geology, landform, soil and veldtypes in the Mahlangeni and Mooiplaas regions. 


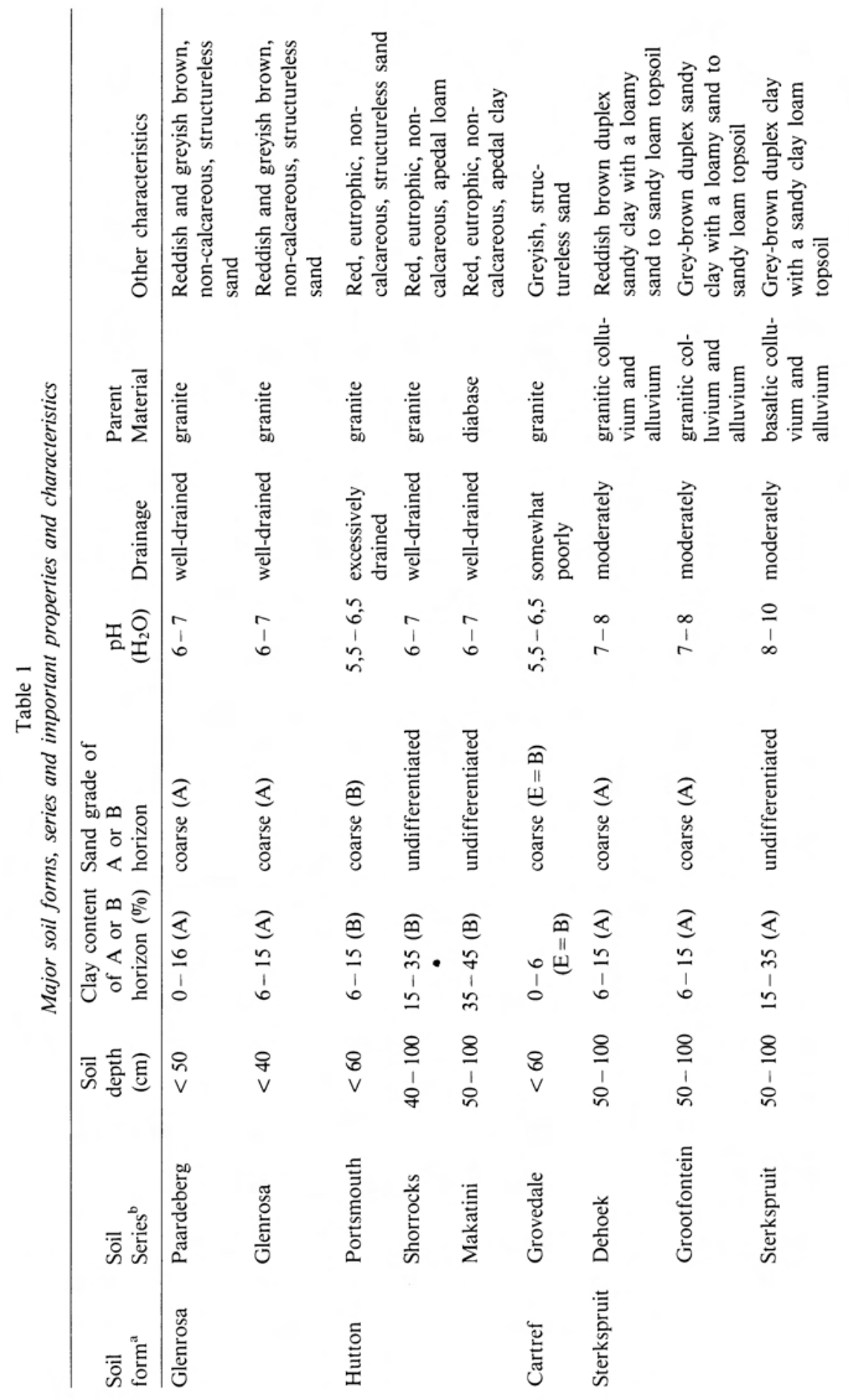




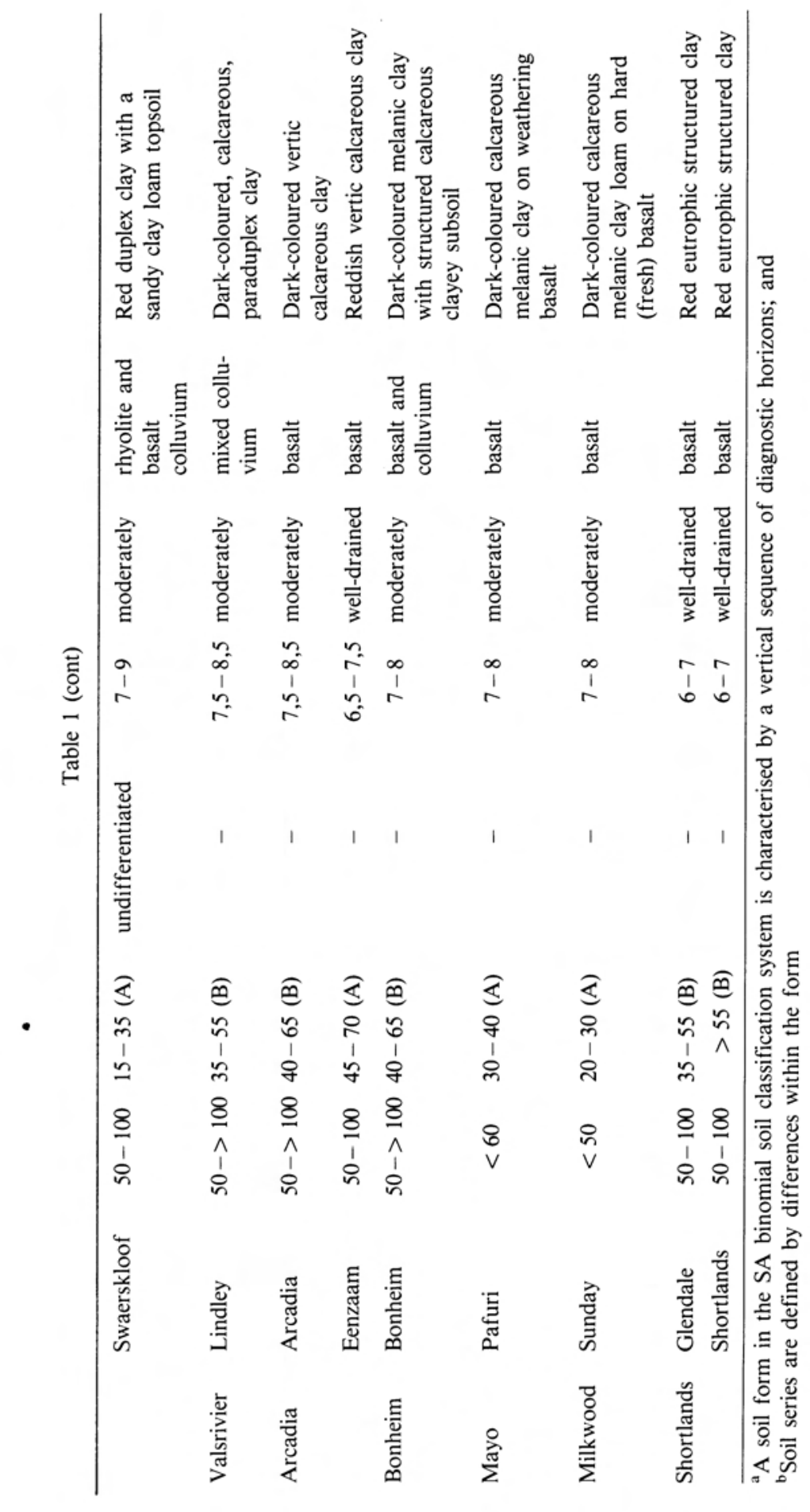


scarcely $45 \mathrm{~m}$ above the plain. The drainage density varies from medium in the Mahlangeni region to low in the Mooiplaas region with only two major rivers - the Tsende and Nshawu - draining the area.

The soils

Two macro soil associations which are closely related to the underlying rock formations occur: shallow, coarse sandy soils and duplex soils derived from the granitic gneiss of the Mahlangeni area; and dark and red clays associated with the basalt flats of the Mooiplaas area (Fig. 2).

The major soil forms and soil series of the study area and their important properties and characteristics are summarised in Table 1.

On the basalt three broad zones of clay-rich soils have developed with a northsouth alignment (Fig. 2). These are from west to east: a narrow zone of shallow and extremely stony, dark, calcareous clays of Arcadia, Bonheim and Milkwood forms associated with the zones of low hills and outcrops of Mashikiri Nephelinite; a wide zone of shallow to moderately deep, dark, calcareous clays of the Mayo, Bonheim and Arcadia forms associated with Letaba Basalt; and a wide zone of moderately deep, red, structured clays of the Shortlands and Arcadia forms associated with Sabie River Basalt. All these soils have a high magnesium and calcium content and are fully base saturated.

In the typical undulating granitic terrain characteristic soil bodies have formed in distinct landscape positions. Shallow, coarse, sandy soils of the Glenrosa and Hutton forms occur on the extensive crests and middle slopes. These are bordered on the footslopes by a narrow zone of moderately deep Cartref soils with bleached, coarse, sandy subsoil horizon. In the valley bottoms are areas of duplex soils mainly of the Sterkspruit form. This toposequence has a characteristic subsurface throughflow of water that has lead to, and maintains these soils in, their distinctive downslope pattern (Fraser 1983).

The coarse sandy soils of crests allow rapid infiltration of rainfall and good internal drainage with downslope subsurface flow. At the bottom of the slope, clayey soils developed. Their drainage is poor and with low leaching, sodium accumulates on the clay complex. A high sodium content increases the $\mathrm{pH}$ to a level where calcium carbonate precipitates, resulting in a sodium saturated dispersed clay fraction. The soil then develops a hard impermeable prismatic structure which impedes the internal drainage and causes a temporary and seasonal build-up of subsurface water. Where this happens iron oxide is reduced, and, together with the clay, removed by lateral movement of the water subsequently forming a bleached sandy horizon (Purves 1975).

On the diabase/dolerite dykes and gabbro sills clay-rich soils of the Hutton form have developed. Like the soils of the basalt, they have a high magnesium and calcium content and are fully base-saturated.

These contrasting soils arising from different lithological origins and relief factors have exerted a marked influence on the species composition and morphology of certain species within the plant communities. 


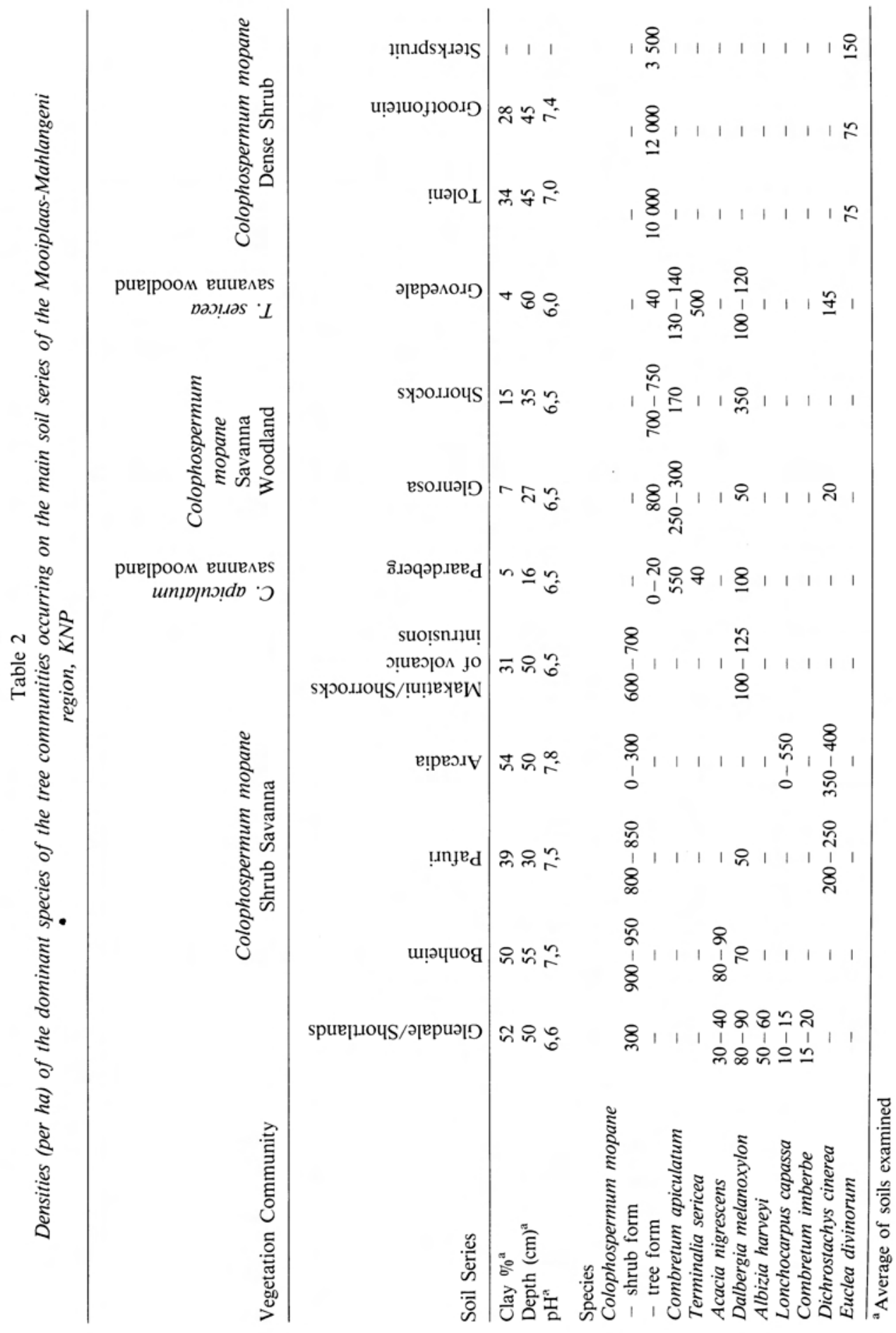




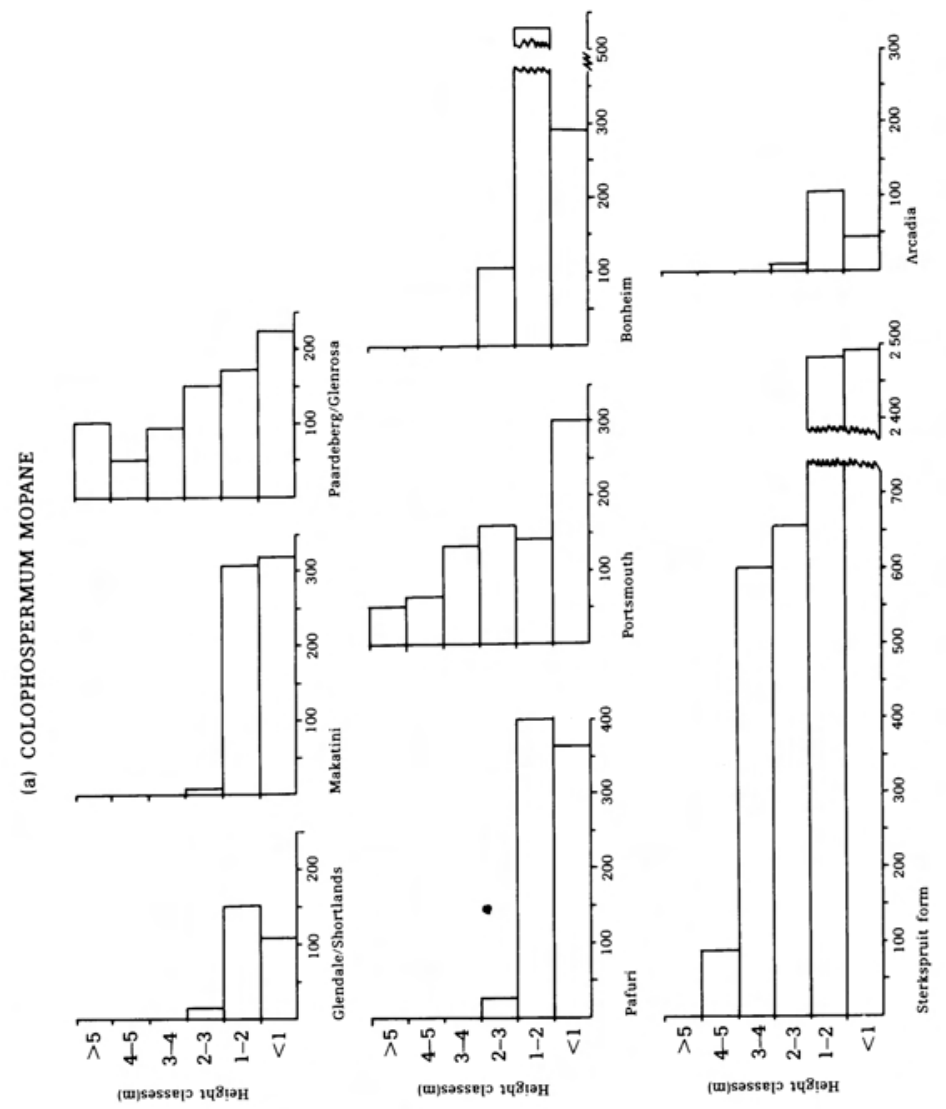



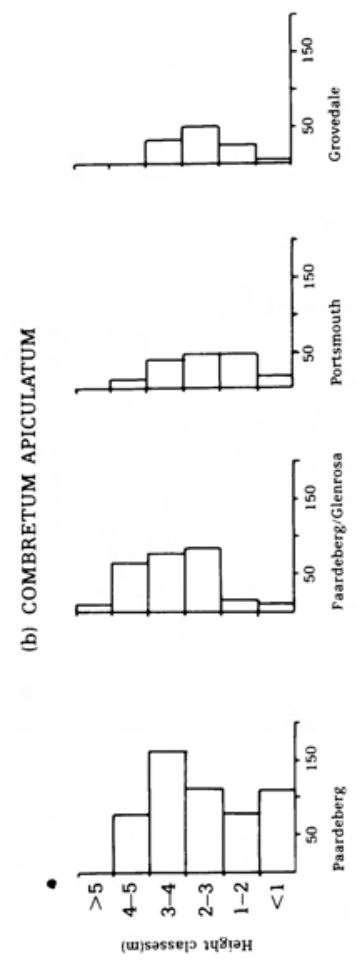
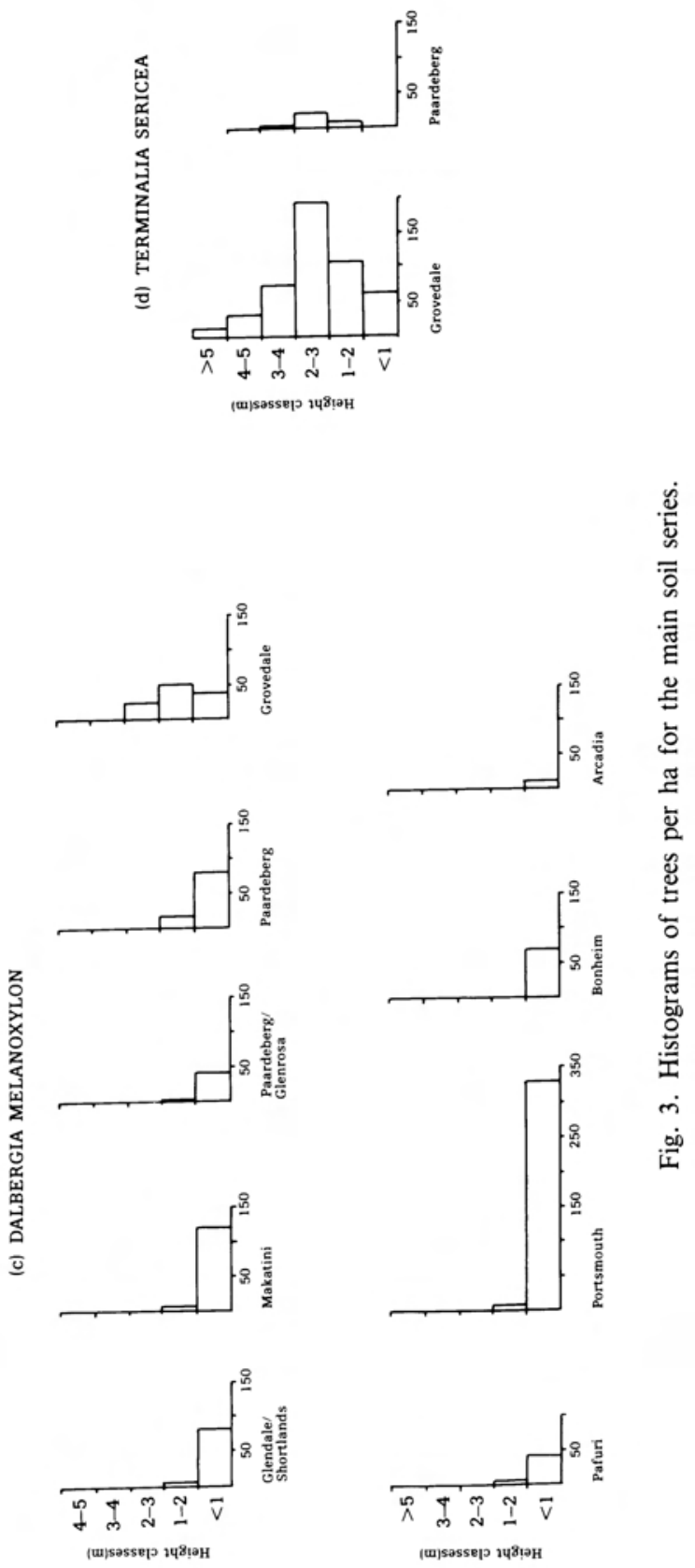


\section{Vegetation}

Only 10 of a total of 61 species of trees identified within the study area form the principal components of the tree communities on the twelve main soil series (Table 2). In Table 2 and Figure 3 one can see that the clay-rich soil derived from basic rocks supports a shrub savanna dominated by mopane Colophospermum mopane (Kirk ex Benth.) Kirk ex J. Leonard which grows as a multiple-stemmed shrub. However, density of the shrub mopane differs significantly between certain of these soils (Table 3), and together with difference in composition and density of other species forms a distinct community on each soil.

Table 3

Levels of significance in the difference between the density of mopane shrub on the clay soils

\begin{tabular}{l|c|c|c|c|}
\hline Soil series & $\begin{array}{c}\text { Shorrocks/ } \\
\text { Makatini }\end{array}$ & Arcadia & Pafuri & Bonheim \\
\hline Glendale/Shortlands & 1 & 1 & 3 & 2 \\
Bonheim & 0 & 2 & 0 & - \\
Pafuri & 0 & 4 & - & \multicolumn{2}{|}{} \\
Arcadia & 2 & - & \\
Shorrocks/Makatini & - &
\end{tabular}

Levels of significance (Students t-test)

$0=$ not significant

$1=$ significant at a level of $10 \%$

2 = significant at a level of $2 \%$

$3=$ significant at a level of $1 \%$

4 = significant at a level of $0,1 \%$

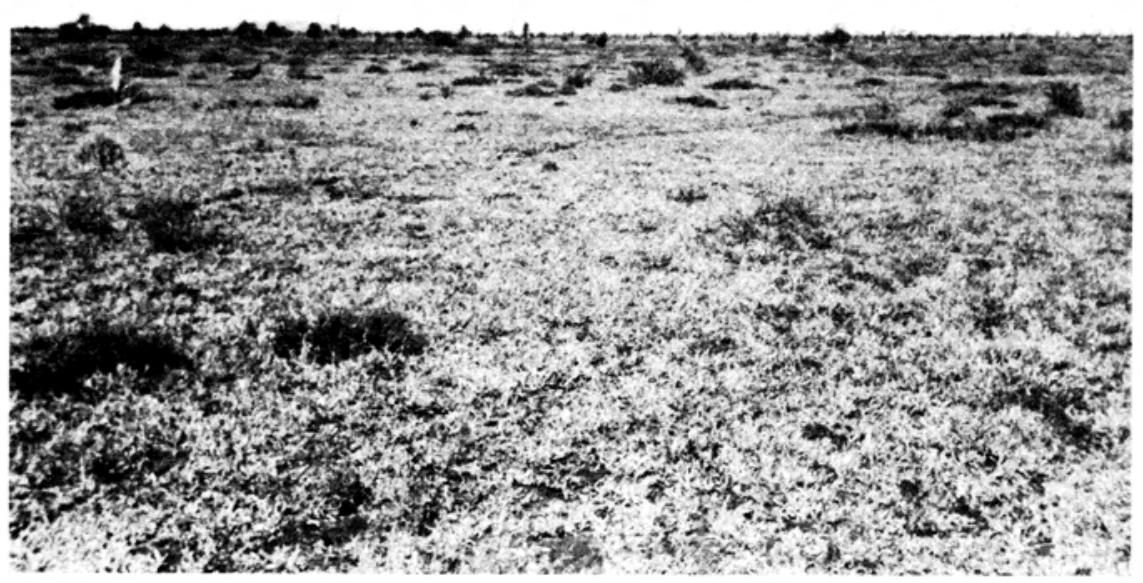

Fig. 4. Open grassland on Arcadia soils. 


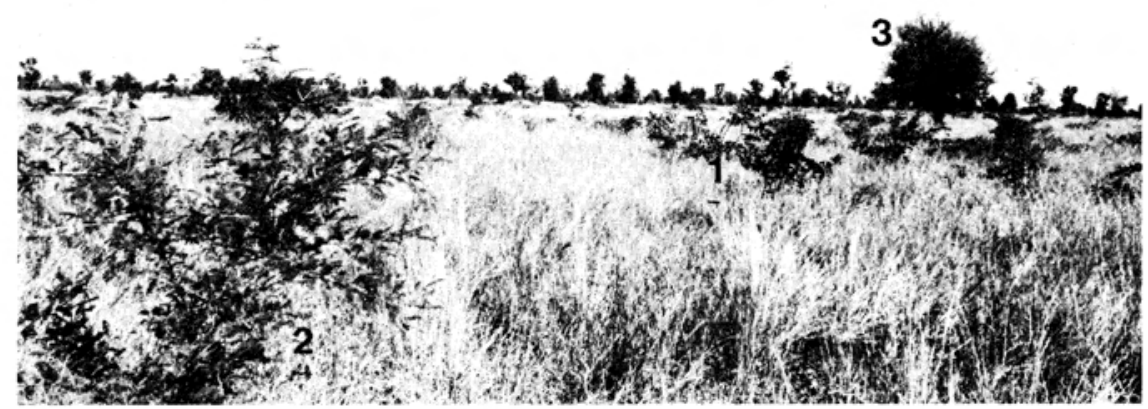

Fig. 5. Vegetation community on Glendale-Shortlands soil association. 1. Colophospermum mopane - shrub. 2. Albizia harveyi. 3. Combretum imberbe.

Most distinctive are the extensive areas of Arcadia soils (Fig. 4) with a low density of shrub mopane, short grass and sekelbos Dichrostachys cinerea (L.) Wight \& Arn. The latter occurs as a weak shrub, seldom growing taller than a metre, and at a density of $350-400$ per hectare. Equally distinctive is the community on Glendale-Shortlands soils (Fig. 5) with a low density of mopane and species like common false-thorn Albizia harveyi Fourn. and leadwood Combretum imberbe Wawra which are not found extensively on other soils. The latter most commonly occurs as trees of less than $2 \mathrm{~m}$ high, sometimes as tall trees, and numerous dead specimens may also be found. Mopane has its highest density on the soils of the Bonheim and Pafuri series which again differs in other species (Table 2, Fig. 6).

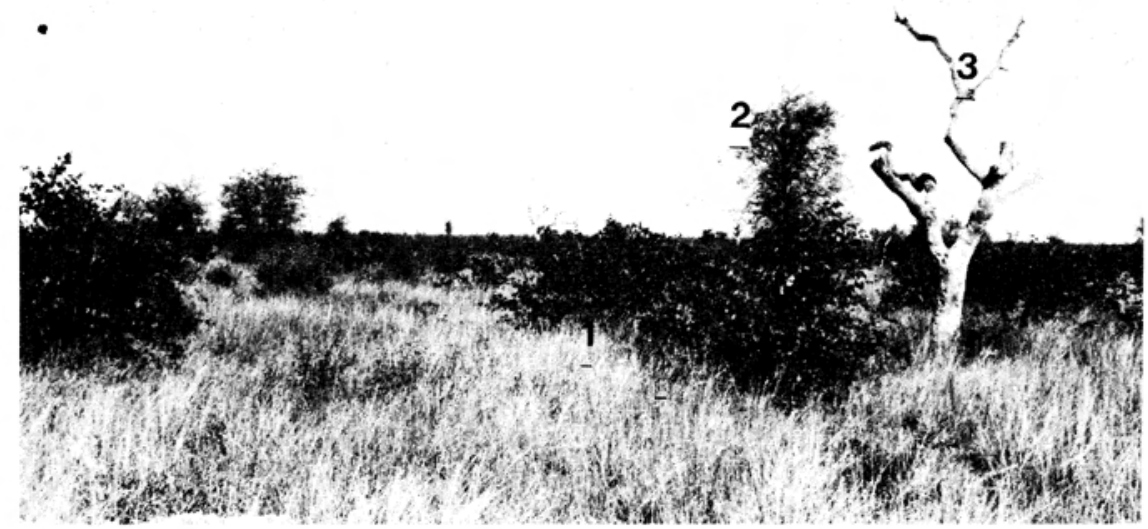

Fig. 6. Vegetation on the Pafuri series. 1. Colophospermum mopane - shrub. 2. Acacia nigrescens. 3. Combretum imberbe - dead. 


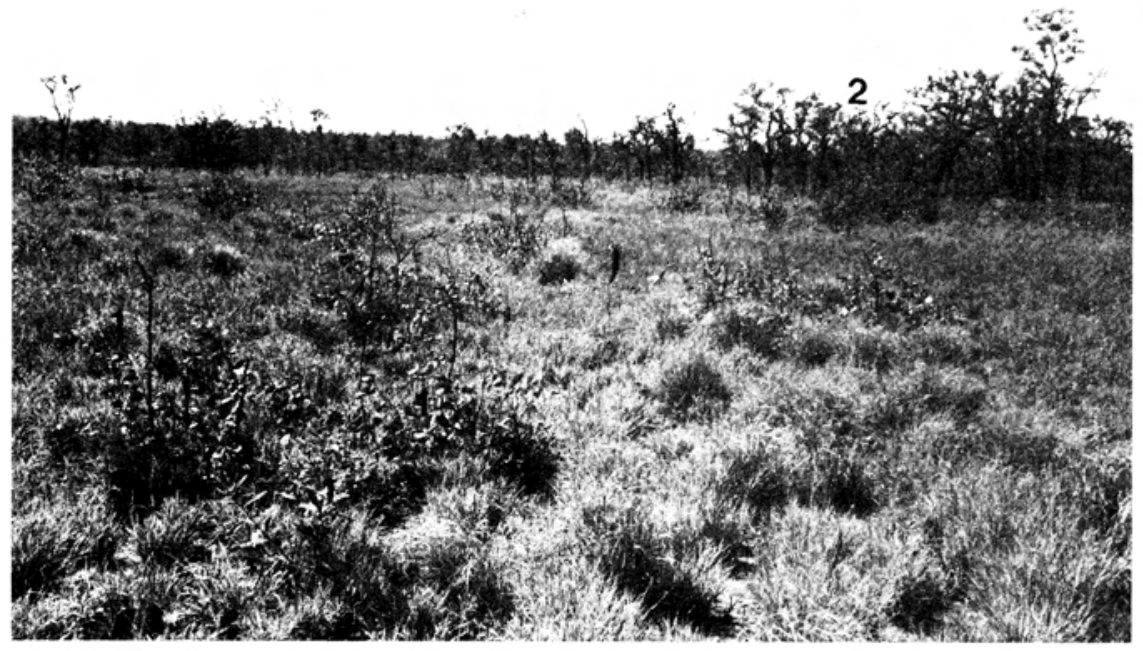

Fig. 7. The shrub savanna of soils on sills and dykes of basic rocks associated with the tall woodlands of the Mahlangeni region. 1. Colophospermum mopane -- shrubs. 2. Colophospermum mopane - trees.

The community on the Makatini-Shorrocks soils is similar to that of the Pafuri. The occurrence of the latter soils is clearly discernible as tall woodlands, suddenly giving way to narrow belts of shrub mopane that follow the paths of the dykes, or to broad tracts that cover gabbro sills (Fig. 7).

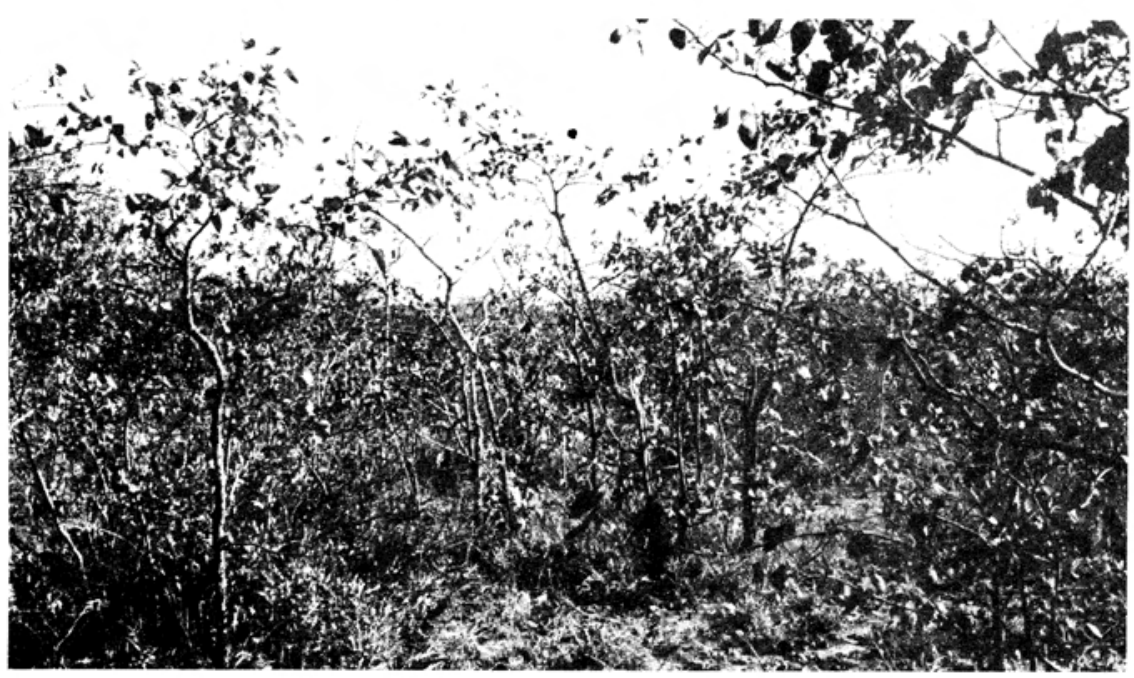

Fig. 8. The form of Colophospermum mopane growing on Sterkspruit soils. 
Savanna woodlands occur on the sandy soils derived from granite. However, each soils series has a distinctive community differing in the dominant tree and densities of other species (Table 2).

Finally, on the duplex soils mopane grows in dense stands (Table 2), and has a stunted tree-like appearance and is generally less than $2 \mathrm{~m}$ high (Fig. 8).

Certain stretches of duplex soils flanking the larger drainage courses are treeless and covered only with short grass. These soils are very saline $(\mathrm{pH} \mathrm{10}$; ECs 1300 $\mathrm{mS} / \mathrm{m}$ ). Such brackish flats appear to be a feature of granitic terrain in the KNP, as similar areas have been described in the southern section of the park (Webber 1979).

Relationship between soils and some common trees

\section{Colophospermum mopane}

In the Mooiplaas-Mahlangeni region the mopane is found in three distinct morphological forms:

(i) multiple-stemmed shrubs with a modal height of $1 \mathrm{~m}-2 \mathrm{~m}$, and growing on all soils derived from basic material i.e. basalt, diabase/dolerite and gabbro;

(ii) single-stemmed trees of up to $5 \mathrm{~m}$ tall growing on sandy soils;

(iii) single-stemmed shrubs or stunted trees growing in dense stands on duplex and paraduplex soils (Fig. 8).

A number of botanists have commented on the morphology and growth of mopane. Henning \& White (1974) have proved that the mopane is very resistant to drought. Their field studies suggested that nitrogen and phosphorus supply and available water influence the growth of mopane. However, laboratory experiments did not confirm this.

Le Roux (1980) in a study in the Etosha National Park in South West Africa, found the mopane both as a tree forming woodlands and as a multiple-stemmed shrub forming shrublands. He suggested three possible causes for this difference in morphology. Firstly, if the moisture and nitrogen levels were favourable, mopane would grow into a tree but if the magnesium status was high and the nitrogen and moisture status low, the shrub form would predominate. Secondly, low nitrogen status in the soil may retard growth, rendering young trees more susceptible to fire damage over long periods. If both nitrogen and magnesium (i.e. the entire cation range) were low, mopane would not establish itself at all. Thirdly, Le Roux stated that notwithstanding the above, it was possible that the difference in morphology was due to different moisture regimes alone.

Although the above factors were not evaluated for this study, it is clear that soil influences the growth, and that mopane with the shrub form is found only on soils having a high clay, magnesium and calcium content, and the tree form on sandy soils low in clay. The mopane is absent from shallow stretches of Paardeberg soils possibly due to competition from the red bushwillow Combretum apiculatum Sond. (see below for discussion on this point). On duplex and para- 
duplex soils the mopane reaches a very high density and has a characteristic stunted form. In contrast, on deep Oakleaf form soils of riverbanks, large mopane trees of up to $20 \mathrm{~m}$ high are found in mixed woodlands.

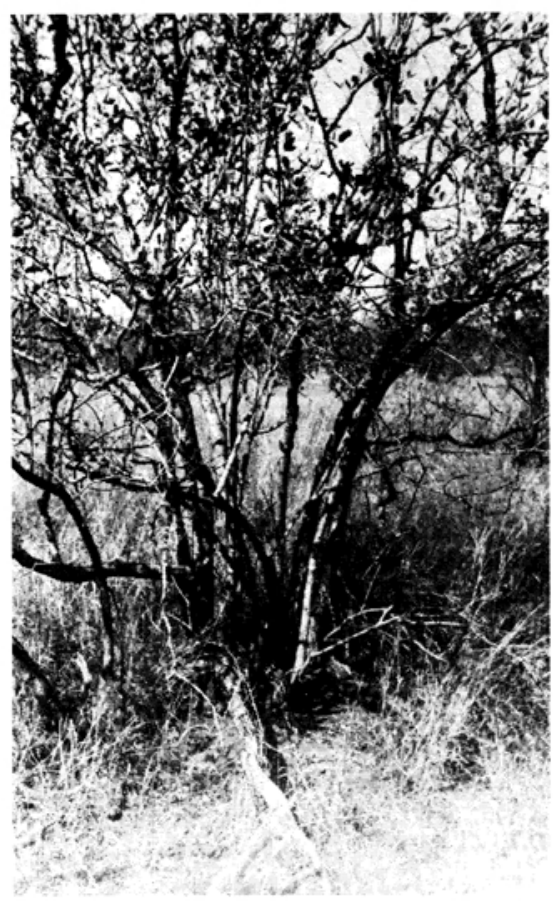

Fig. 9. Multiple-stemmed Combretum apiculatum tree.

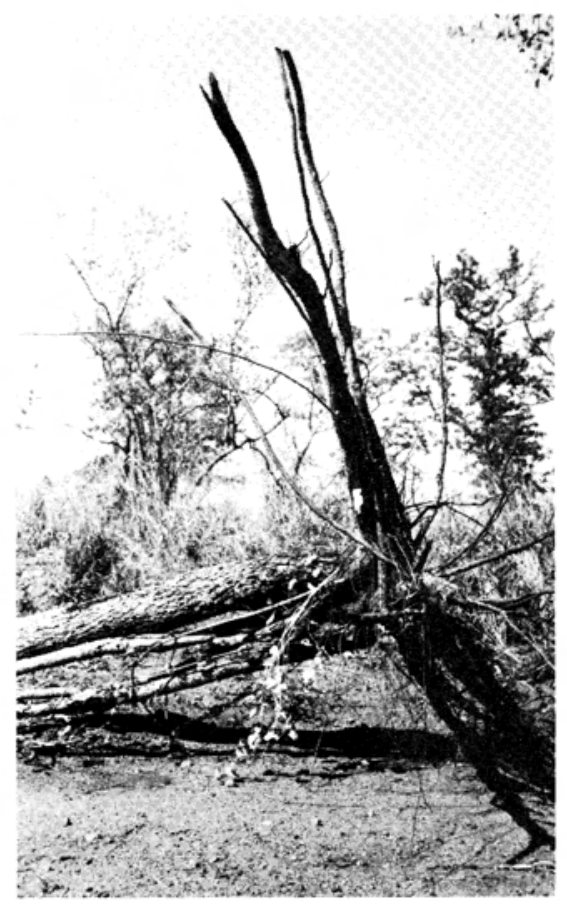

Fig. 10. A Combretum apiculatum uprooted by elephant and showing its well-developed lateral root-system.

\section{Combretum apiculatum}

This tree is found only on well-drained sandy and rocky soils (Van Wyk 1972) which accounts for its distribution being limited to the Mahlangeni region and a few rocky outcrops in the Mooiplaas region. It grows as a multiple-stemmed tree (Fig. 9) and has a lateral wide-spreading root system (Fig. 10). Dominant on very shallow Paardeberg soils (Table 4), its wide-spreading lateral rootsystem allows it to utilise water from a large area of the shallow soils, and it is tentatively suggested that this gives the tree a competitive advantage over the mopane in shallow soils. In deeper soils its density drops and mopane dominates. The red bushwillow is essentially a tree of well-drained crestal soils and does not occur on the lower footslopes and bottomlands where the drainage is slow. 
Table 4

Depths of A horizons of Paardeberg and Glenrosa soils for two different woodlands of the Mahlangeni region

\begin{tabular}{lccccc}
\hline & $\begin{array}{c}\text { Range of } \\
\text { depth } \\
(\mathrm{cm})\end{array}$ & $\begin{array}{c}\text { Average } \\
\text { depth } \\
(\mathrm{cm})\end{array}$ & $\begin{array}{c}\text { Standard } \\
\text { diviation }\end{array}$ & $\begin{array}{c}\text { No. of } \\
\text { obser- } \\
\text { vations }\end{array}$ & $\begin{array}{c}\text { Students } \\
\text { tests } \\
\text { t-value }\end{array}$ \\
\hline $\begin{array}{l}\text { Colophospermum } \\
\text { mopane and }\end{array}$ & $10-60$ & 22,63 & 10,68 & 78 & \\
$\begin{array}{l}\text { Combretum } \\
\text { apiculatum } \\
\text { woodland }\end{array}$ & & & & & $3,324^{*}$ \\
$\begin{array}{l}\text { Combretum } \\
\text { apiculatum } \\
\text { woodland }\end{array}$ & $5-30$ & 16,78 & 7,16 & 31 & \\
\hline
\end{tabular}

* difference significant at a level of $1 \%$

\section{Terminalia sericea}

According to Van Wyk (1972) the preferred habitat of the silver cluster-leaf Terminalia sericea Burch. ex DC, is deep, well-drained soils but abounds only on two shallow, poorly drained soils: Grovedale series (Cartref form) where it dominates (Table 2), and Paardeberg series (Glenrosa form). The Grovedale soil has an average depth of $65 \mathrm{~cm}$, consists mainly of a coarse E horizon, and occurs only in long narrow belts between the shallow crestal soils and the duplex soils of the footslopes and valley bottoms. This soil has formed in a zone of periodic wetness. During the rains water infiltrates the crestal soils and flows freely downslope through the soil until it meets the more impervious bottomland duplex soils. The water then accumulates along the edge of the latter and in the E horizon of the Grovedale. This suggests that trees growing in this zone have a higher water requirement than those of crestal soils. Webber (1979) also found that the silver cluster-leaf was dominant in the Cartref form soils found in the corresponding zone in the landscape of the southern granitic area of the Kruger National Park.

\section{Conclusion}

There is a distinct relationship between the soils and the tree communities within the Mooiplaas-Mahlangeni region. The lithological origin of the parent material of the soils exerting, as it does, a major influence on the morphology of the soils, is reflected in the vegetation, even to the extent of minor volcanic intrusions. Soils developing in distinct landscape positions are likewise reflected in the type and morphology of the trees. Although not investigated it appears that the edaphic factor of the soils affect the growth and morphology of the mopane.

The often close correlation between the soils and vegetation of a region can allow the latter to be an indicator of the soil type and is a very useful aid in mapping 
soils. For example, shrub mopane is indicative of soils derived from basic rocks, and this is true even of the narrow diabase dykes in the granitic terrain where the dykes are indicated by shrub mopane in which it appears like a swarth cut through the woodlands.

\section{References}

CLEVERLY, R.W, and J.W. BRISTOW. 1979. Revised volcanic stratigraphy of the Lebombo Monocline. Trans. geol. Soc. S. Afr. 82: 227-230.

ERASER, S.W. 1983. Soil studies of the Mooiplaas-Mahlangeni region, Centrat Kruger National Park. M.Sc. thesis, Univ. of South Africa, Pretoria.

HENNING, J. 1980. Hydrological characterization of soils under selected sub-habitats in a Burkea-Eragrostis ecosystem. M.A. thesis, Univ. of South Africa, Pretoria.

HENNING, A.C. and R.E. WHITE. 1974. A study of the growth and distribution of the Colophospermum mopane (Kirk ex Benth.) Kirk ex. J. Leon.: The interaction of nitrogen, phosphorus and soil moisture stress. Proc. Grassld. Soc. sth. Afr. 9: 53-61.

KRUCKEBERG, A.R. 1969. The implications of ecology for plant systematics. Taxon. 18: $92-120$.

LE ROUX, C.J.G. 1980. Vegetation classification and related studies in the Elosha National Park. D.Sc. thesis, Univ. of Pretoria, Pretoria.

MACVICAR, C.N., J.M. DE VILLIERS, R.F. LOXTON, E. VERSTER, J. LAMBRECHTS, F.R. MERRYWEATHER, J. LE ROUX, T.H. VAN ROOYEN and H.J. VON M. HARMSE. 1977. Soil classification: A binomial system for South Africa. Sci. Bull. No 390. Pretoria: Dept. agric. tech. Serv. Rep. S. Afr.

MASON, H.L. 1946. The geographic occurrence of plants of highly restricted patterns of distribution in "The edaphic factors in narrow endemism". Madrono 8.

PURVES, W.D. 1975. Genesis and management of some granite-derived soils. Rhod. Sci. News. 9: $80-81$.

VAN WYK, P. 1972. Trees of the Kruger National Park. 2 Volumes. Cape Town: Purnell.

WEBBER, C.N. 1979. The effects of fire on soil-plant ecological relationships in the southern part of the Kruger National Park: a study in soil geography. M.Sc. thesis, Univ. of South Africa, Pretoria. 